\title{
Prospective Utility: A New Interpretation of the Utility Requirement of Section 101 of the Patent Act
}

\author{
Nathan Machin $\dagger$
}

\section{TABLE OF CONTENTS}

Introduction

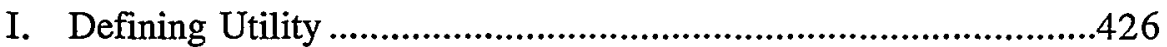

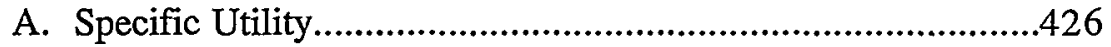

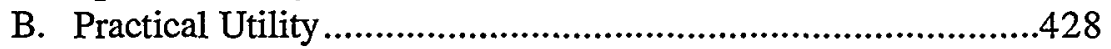

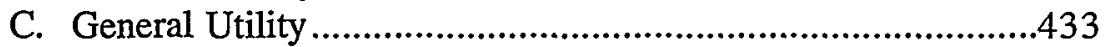

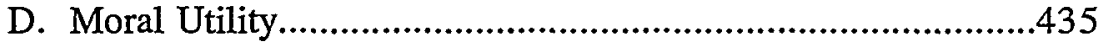

E. The Utility Requirement: Reality and Potential.......................436

II. Formulating a New Definition of Utility......................................437

A. Problems with the Current Utility Doctrine............................437

1. Tension with the Constitution.........................................437

2. Mllusory Benefits of the Current Utility Doctrine...............438

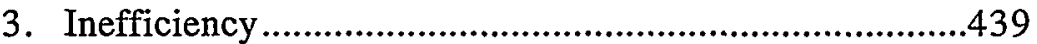

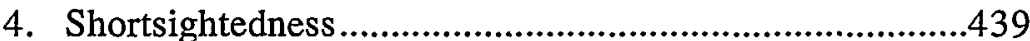

B. A New Formula for Determining Utility................................440

III. Applying the Prospective Utility Formula ...................................442

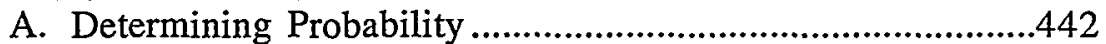

1. Inventions with Current Utility ..........................................443

2. Inventions without Current Utility ....................................443

a. New Species within Known Genera...............................444

b. New Species within New Genera:

Commercial Success as an Indication of Utility ...............445

B. Determining Magnitude.......................................................449

Copyright $(1999$ California Law Review, Inc.

$\dagger$ J.D. Candidate 1999, Boalt Hall School of Law, University of California, Berkeley; Ph.D., University of California, Berkeley, 1995; B.A., University of Oregon, 1988. I would like to thank Professor Robert Merges for his guidance. Thanks to Gillian Brown, Julie Jauregui Holloway, Matthew Kline, Deirdre Conley, Alison Howard, and the other members of the California Law Review for generously contributing their time and energy. Special thanks to Victoria Pond for her unflagging encouragement and support. 
C. Combining Probability and Magnitude:

The Formula at Work.

1. Inventions with One Prospective Use.

2. Inventions with More Than One Prospective Use. 452

D. Interaction with Other Aspects of Patent Law

1. Enablement 453

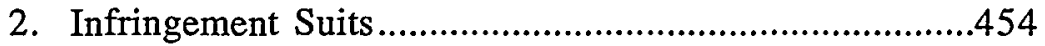

Conclusion .454 


\title{
Prospective Utility: A New Interpretation of the Utility Requirement of Section 101 of the Patent Act
}

\author{
Nathan Machin
}

This Comment attempts to reconcile the Constitution, the Patent Act, and court decisions addressing the utility requirement of patentability. The author identifies the following precepts behind the utility requirement: the goal of the patent system is to promote the progress of the useful arts; the word "useful" in section 101 of the Patent Act should be interpreted reasonably; and the current definition of "useful" creates a broad class of "useless" inventions, some of which are more useless than others. Based on these precepts, the current system is deficient. In place of the current system, the author proposes the "prospective utility doctrine" as a better formula for determining utility. This doctrine differs from current definitions of utility in three major ways. First, it defines usefulness as promoting the progress of the useful arts. Second, it allows an applicant to establish utility by demonstrating that a person of ordinary skill in the art would reasonably believe that an invention has a reasonable chance of being matched with a significant use in the foreseeable future. Third, it allows the patent applicant to present evidence of commercial success as evidence of utility. Unlike the current utility requirement, which requires special rules to be applied to certain classes of inventions, the prospective utility requirement applies a uniform set of requirements to all inventions. The prospective utility requirement may also be used to address the persistent problem of nominal utility, in particular with respect to the current controversy surrounding the patenting of human gene fragments without known functions.

\section{INTRODUCTION}

Among Congress' enumerated constitutional powers is the power to grant patents. ${ }^{1}$ Congress passed the first Patent Act in $1790 .{ }^{2}$ In all but

1. See U.S. CoNsT. art. I, § 8, cl. 8. A patent confers on its holder a limited monopoly that allows her to exclude others from making, using, selling, or importing the claimed invention without a 
the details, it is remarkably similar to the most recent version of the Patent Act, which Congress passed in 1952. ${ }^{3}$ The Patent Act imposes several requirements on inventors. First, the invention must comprise patentable subject matter. ${ }^{4}$ Second, the invention must be useful. ${ }^{5}$ Third, the invention must be novel. ${ }^{6}$ Fourth, the application must be filed in a timely manner. ${ }^{7}$ Fifth, the invention must be a nonobvious variation of the prior art. $^{8}$ Sixth, the application must describe the best method of making or using the invention so as to enable one of ordinary skill in the art to practice the invention. ${ }^{9}$

The second requirement, utility, is the focus of this Comment. The utility requirement is rooted in the Constitution: Article I empowers Congress to grant patents for contributions to the "useful Arts."10 Congress codified its patent power in section 101 of the Patent Act of 1952 by explicitly requiring that patentable inventions be "useful." The usefulness, or utility, of a patent is derived from an understanding of patent law based on contract law. ${ }^{12}$ In this view, patents are analogous to contracts between the inventor and society..$^{13}$ Under the common law,

license from the patentee. See 35 U.S.C. § 154(a)(1) (1994). Under current U.S. law, patent proteetion usually lasts for twenty years from the date the application is filed. See 35 U.S.C. $\S$ 154(a)(2) (1994). After a patent expires, anyone may use, sell, or import the invention without regard to the inventor's wishes. See generally Robert Patrick Merges, PATENT LAw AND POLicy 35-49 (2d ed. 1997).

2. See Patent Act of 1790 (1790).

3. See Patent Aet of 1952, 35 U.S.C. § 1-376 (1994).

4. See id. $\$ 101$.

5. See id.

6. See id. $\S 102$.

7. See id.

8. See id. $\$ 103$ (a). "Prior art" is defined relative to each invention. lt is the entire body of public knowledge that pertains to the field of the invention and that exists prior to the creation of the invention. Prior art includes inventions, scholarly articles and lectures, dissertations, etc. See JoSEPH R. Nolan ET AL., Black's LaW DictionaRY 1193 (6th ed. 1990). It also includes publie knowledge from "analogous arts"-that is, knowledge outside of the field of the invention but which is pertinent nonetheless. Compare George J. Meyer Mfg. Co. v. San Marino Elec. Corp., 422 F.2d 1285 (9th Cir. 1970) (holding bottle scanning device obvious in light of missile tracking system technology), with In re Clay, 966 F.2d 656 (Fed. Cir. 1992) (holding method of storing refined oil products not rendered obvious by an earlier patent issued to the applicant for a similar technique used to increase oil field production).

9. See 35 U.S.C. § 112 (1994).

10. U.S. CONST. art. I, $\$ 8, \mathrm{cl} .8$.

11. 35 U.S.C. $\$ 101$ (1994).

12. See 1 William C. Robinson, The Law of Patents for Useful Inventions $462-63$ (1890). This analogy is inperfect. For example, the patent "contraet" can be asserted by one of its "parties" (the patentee) against third parties (infringers) in a way that genuine contracts cannot be. Also, equitable remedies (in the form of specific performance) are rare in contract law, see MARviN A. Chirelstein, Concepts and Case analysis in the Law of Contracts 145-46 (2d ed. 1993), but common (in the form of injunctions against infringement) in patent law, see 35 U.S.C. § 283 (1994).

13. See, e.g., Bonito Boats, Inc. v. Thunder Craft Boats, Ine., 489 U.S. 141, 150-51 (1989) ("The federal patent system thus embodies a carefully crafted bargain for encouraging the creation 
each party to a contract must provide consideration. ${ }^{14}$ In the patent context, society's consideration is the limited monopoly it grants to the inventor. In return, the imventor offers consideration in the form of disclosure to society of a useful invention. ${ }^{15}$ If the invention is useless, then the inventor has not provided consideration. Without consideration, the "contract," that is, the patent, is not enforceable. ${ }^{16}$ The usefulness requirement therefore provides grounds for a third party to attack the patent in a civil action. For example, when a patent holder brings an infringement suit, the defendant-a third party to the contract between the patent holder and society-can challenge the enforceability of the patent, or contract. If the defendant can prove that the invention lacked utility, or consideration, then the patent will be declared unenforceable and the plaintiff will lose her infringement suit. ${ }^{17}$

Throughout the history of the patent law, the utility doctrine has been remarkably malleable. Its simple language is like the ink blots of a Rorschach test: different observers see in it different things. Nevertheless, utility is required by the Patent Act. ${ }^{18}$ For the utility doctrine to be a vital component of patent law, it must impose at least minimal requirements on an invention. It must divide the world of inventions into "patentable" and "non-patentable" categories in a way that is different than the division imposed by the other requirements for patentability. ${ }^{19}$ In addition, the utility doctrine must further the patent system's goals consistent with the system's policies.

This Comment seeks to develop a better understanding of the utility doctrine than currently exists. This new understanding derives from the constitutional origins of the utility requirement and from the policy goals underlying the patent system, and leads to a new interpretation of utility, called "prospective utility." Unlike previous interpretations of utility, which are discussed in Part I of this Comment, prospective utility both recognizes the present value of a potential future use of an

and disclosure of new, useful, and non-obvious advances in technology and design in return for the exclusive right to practice the invention for a period of years.").

14. See Restatement (Second) of Contracts $\$ \$ 17,71$ (1981); Chirelstein, supra note 12, at 11-13.

15. In the United States, each patented invention is made public upon grant of the patent. See 35 U.S.C. § 11(a)(1) (1994); 37 C.F.R. \$ 1-11 (1997). Patent applications are kept confidential. See 35 U.S.C. \$ 122 (1981). By contrast, in Europe and Japan, patent applications are published eighteen months after they are filed. See MERGES, supra note 1, at 49.

16. See supra note 14.

17. See 35 U.S.C. \& 282(2) (1994). Sone cases have lield that use of the patented invention by the defendant in an infringement suit estops the defendant from attacking the utility of the patent, on the theory that the defendant cannot use a useless invention. See Enterprise Mfg. Co. v. Shakespeare Co., 141 F.2d 916 (6th Cir. 1944). But commentators have strongly criticized that view. See generally 1 Donald S. Chisum, Chisum on Patents, at § 4.04[5] (1997).

18. See 35 U.S.C. $\$ 101$ (1994).

19. See supra notes $4-9$ and accompanying text. 
invention, and takes commercial aspects of the invention into account. Recognizing these differences, Parts II and III discuss the practical benefits and problems created by the implementation of this proposed doctrine. In its Conclusion, this Comment argues that several factors militate in favor of adopting the prospective utility doctrine.

I

\section{DEFINING UTILITY}

In spite of its constitutional origins and its apparent simplicity, the utility requirement has had a tumultuous history. ${ }^{20}$ The problem centers on the meaning of the word "useful" in the Patent Act. ${ }^{21}$ The courts have provided a variety of defmitions which dissects the utility requirement into two basic requirements. Specific utility requires that an invention work. General utility requires that an invention address a human want or need. Each of these definitions may be resolved further into more focused definitions of utility. Practical utility is a form of specific utility. It requires that inventions intended for therapeutic use meet certain heightened standards. Moral utility is an interpretation of general utility. It requires only that an invention not be harmful. Each of these definitions is discussed in turn.

\section{A. Specific Utility}

The specific utility requirement is the most fundamental of the utility requirements. "Specific utility," or "operativeness," is a question posed by both patent examiners and the courts: does the invention actually work? For example, a device purported to roll sheet metal into tubes, but which instead only inangles the sheet metal, clearly fails the test of specific utility. The applicant's burden for proving specific utility, however, varies according to the type of invention she claims.

In In re Chilowsky, ${ }^{22}$ the Court of Customs and Patent Appeals (C.C.P.A.) - the forerunner to the Court of Appeals for the Federal Circuit-divided inventions into three categories for purposes of determining the applicant's burden in proving specific utility. First, if the claims "can be readily understood and conform[] to the known laws of physics and chemistry, [specific utility] is not questioned, and no further evidence is required." ${ }^{23}$ That is, patent examiners cannot question the specific utility of an invention that obviously is in line with known scientific primciples. This group contains the majority of claimed

20. For a discussion of the development of the utility doctrine and its current status, see generally 1 Chisum, supra note 17 , at eh. 4 .

21. 35 U.S.C. $\$ 101$ (1994).

22. 229 F.2d 457, 462 (C.C.P.A. 1956).

23. Id. 
inventions. ${ }^{24}$ Second, "if the alleged [specific utility] seems clearly to conflict with a recognized scientific principle...the presumption of [lack of specific utility] is so strong that very clear evidence is required to overcome it."25 Archetypal examples ${ }^{26}$ of this group are perpetual motion machines, ${ }^{27}$ baldness cures, ${ }^{28}$ and grandiose medical claims. ${ }^{29}$ Third, "[when] the device involved [is] of such a nature that it [cannot] be tested by any known scientific principles ... it is incumbent on the applicant to demonstrate the... [specific] utility of the device and make clear the principles on which it operates." 30

The distinction between the first and third groups is made by reference to the person of ordmary skill in the art. ${ }^{31}$ Would she question the specific utility of the claimed invention? If not, then the patent applicant has met her burden. If so, then it is incumbent upon the applicant to provide additional evidence of specific utility sufficient to convince the person of ordinary skill in the art. Put another way, if the claims are not inherently incredible (i.e., do not fall imto group two), the specific utility of the invention will be assumed (putting the invention into group one) unless the patent examiner presents evidence that a person of ordinary skill in the art would question the specific utility of the invention (thereby moving the mvention into group three). The burden, which lies initially with the examiner, then shifts to the applicant to provide convimcing evidence of the specific utility of her invention. The amount and type of evidence required to convimce a person of ordinary skill in the art of an invention's specific utility is not always clear. Generally, a

24 For example, virtually all novelties and amusements, software and business methods, on which patents are filed will "conform[] to the known laws of physics and chemistry...." Id. The same may be said of most computer hardware patents. Even most revolutionary pharmaceutical compounds will operate in well characterized ways, for example, as vaccines. See, e.g., U.S. Pat. No. $5,861,243$, Vaccine for Protection Against HIV Infections, Process for Preparing Same, and Their Use as a Diagnostic Agent and Immunotherapeutic Agent.

25. Id. at 462 .

26. See PTO's Overview of Legal Precedent Governing the Utility Requirement \& I(B), reprinted in 49 PAT. Trademark \& Copyright J. 234 (1995) [hereinafter PTO's Overview].

27. See Newman v. Quigg, 877 F.2d 1575 (Fed. Cir. 1989), modified, 886 F.2d 329 (Fed. Cir. 1989) (affirming district court's rejection of the patentability of a perpetual motion machine for, inter alia, lack of utihty).

28. See In re Oberweger, 115 F.2d 826 (C.C.P.A. 1940); In re Ferens, 417 F.2d 1072 (C.C.P.A. 1969). But see Upjohn Co. v. Medtron Lab., 751 F. Supp. 416, 419 (S.D.N.Y. 1990) (describing the arduous, but ultimately successful, prosecution of a patent for the use of Minoxidil as a treatment for baldness).

29. See In re Milligan, No. 97-1093, 1997 U.S. App. LEXIS 6636 (Fed. Cir. Apr. 10, 1997) (affirming Patent and Trademark Office (PTO) Board of Appeals' rejection of applicant's claims as inherently incredible for treatment of arthritis with an aqueous solution of lactic acid).

30. Chilowsky, 229 F.2d at 462.

31. The person of ordinary skill in the art is a hypothetical person "who is presumed to be aware of all the pertinent art." Bausch \& Lomb v. Barnes Hind/Hydrocurve, 796 F.2d 443 (Fed. Cir. 1986) (quoted in Irwin M. Aisenderg, Modern Patent Law Precedent 860 (3d ed. 1997) (listing six factors relevant to a determination of the level of ordinary skill in the art)). 
patent applicant will have an easy time overcoming an examiner's doubt as to her invention's specific utility when a person of ordinary skill in the art to which the patent relates understands the principles of that field.

The Patent and Trademark Office (PTO) has promulgated guidelines for determining the specific utility of an invention that are similar to the Chilowsky test. ${ }^{32}$ The PTO instructs its examiners to follow a threepart protocol for determining utility. ${ }^{33}$ First, the examiner reads the specification to determine what the invention is and whether the applicant has claimed a specific utility. ${ }^{34}$ Second, the examiner evaluates whether the applicant has asserted a credible utility: if the applicant named a specific utility in her application, the examiner determines whether a person of ordinary skill in the art would find it credible. ${ }^{35}$ If so, then the invention is not rejected for lack of utility.$^{36}$ If the applicant did not assert a specific utility in the patent application for her invention, but it has a "well-established utility," then the application is not rejected for lack of utility..$^{38}$ If the applicant does not assert a specific utility and there is no well-established utility for her invention, then sections 101 and 112 force the examiner to reject the claim. ${ }^{39}$ After such a rejection, the applicant may amend her application to assert a specific utility. The new claim would then be examined as discussed above. ${ }^{40}$ Third, if the specific utility claim is not credible and there is no wellestablished utility, then the claim is rejected under sections 101 and 112 of the Patent Act. ${ }^{41}$ Rejections must be premised on a prima facie case of lack of specific utility which requires the examiner to adduce a logical reason, supported by evidence, why a person of ordinary skill in the art would more likely than not doubt the invention's utility. ${ }^{42}$

\section{B. Practical Utility}

Practical utility is a special formulation of specific utility that applies only to applications claiming chemical processes and compounds.

32. See Utility Examination Guidelines, 60 Fed. Reg. 36263 (1995).

33. See id.

34. See id. $\S \mathrm{II}(\mathrm{B})(1)-(2)$.

35. See id. $\$ \mathrm{I}(\mathrm{B})(2)(\mathrm{a})$.

36. See id.

37. "An invention has a well-established utility if a person of ordinary skill in the art would immediately appreciate why the invention is useful based on the characteristics of the invcntion (e.g., properties of a product or obvious application of a process)." Id. $\S$ II (B)(2)(b).

38. See id.

39. See id. $\S \Pi(\mathrm{B})(2)(\mathrm{c})$.

40. See id.

41. See id. $\S \Pi(B)(3)$.

42. See id. $\S \Pi(B)(3)(a)$. A patent application can go through multiple cycles of rejection by the PTO and amendment by the applicant before the patent is finally issued or rejectcd. See 37 C.F.R. $\S \S$ 1.111-1.113, 1.116 (1998). 
It was created by the Supreme Court in the controversial opinion of Brenner v. Manson..$^{43}$ In order to have practical utility, a chemical invention must be useful for something other than chemical or pharmaceutical research. The Supreme Court in effect decided in Manson that, as a matter of law, a person of ordinary skill in the art of chemical synthesis or pharmacology cannot be convinced of the utility of a chemical compound or process useful only in research. ${ }^{44}$ Although neither the Supreme Court nor Congress has considered practical utility since Manson, the PTO and the Federal Circuit in recent years have backed away from the practical utility standard..$^{45}$ Each of these bodies has enunciated utility requirements that are more amenable to the patenting of pharmacological inventions. The unresolved tension between these two conflicting lines of authority creates uncertainty about the vitality of the practical utility requirement, and therefore the standard of utility for chemical inventions.

The applicant in Manson claimed a process for synthesizing a certain class of steroids. ${ }^{46}$ Evidence that the products of the applicant's process were homologues ${ }^{47}$ of a steroid known to be effective in treating tumors in mice failed to convince the PTO that the claimed process had utility. ${ }^{48}$ On appeal, however, the C.C.P.A. found utility. The court required only that the products of the applicant's process be known and not harmful..$^{49}$ The Supreme Court reversed..$^{50}$ In a sweeping opinion, it rejected not only the lower court's reasoning, ${ }^{51}$ but also Judge Story's nineteenth century "moral utility" doctrine ${ }^{52}$ and the acceptability of structural homology arguments for establishing utility. ${ }^{53}$ It also cast

43. 383 U.S. 519 (1966). For a discussion of the case law preceding Manson, see Salim A. Hasan, A Call for Reconsideration of the Strict Utility Standard in Chemical Patent Practice, 9 HigH TहCH. L.J. 245, 251-55 (1994).

44. Looked at another way, the Supreme Court's decision in Manson effectively added inventions useful only in research to products of nature and mathematical formulae as unpatentable subject matter. See 383 U.S. at 535-36. An invention stigmatized as being useful only in research can be rescued from unpatentability by finding an acceptable use for it, thereby removing its stigma. Similarly, mathematical formulae can be patented under certain circumstances. Compare Gottschalk v. Benson, 409 U.S. 63 (1972) (finding a computer program to be an unpatentable algorithm), with In re Alappat, 33 F.3d 1526 (Fed. Cir. 1994) (finding a computer program to be patentable insofar as it causes a physical transformation of the hardware running it).

45. See infra notes $60-81$ and accompanying text.

46. See 383 U.S. at $520-21$ n.1.

47. See id. at 522 n.3 ("A homologous series is a family of chemically related compounds, the composition of which varies from member to member by $\mathrm{CH}_{2}$ (one atoin of carbon and two atoms of hydrogen)... Chemists knowing the properties of one member of a series would in general know what to expect in adjacent members." (quoting Application to Henze, 181 F.2d 196, 200-01 (1950))).

48. See 383 U.S. at 521-22.

49. See id. at 522 .

50. See id. at 536 .

51. See id. at 530-31.

52. See id. at 533-35; see also discussion infra Section 1.D.

53. See Manson, 383 U.S. at 531-32. 
doubt on the vitality of utility arguments based on animal tests. ${ }^{54}$ The Court was concerned with granting patent protection to trivial or inchoate inventions. With its famous declaration that "a patent is not a hunting license," ${ }^{55}$ the Court seemed to require that the utility of any invention claiming a pharmaceutical use be proved with clinical data.

The C.C.P.A. initially embraced and extended the Manson holding in two companion cases. In In re Kirk, ${ }^{56}$ the court held that chemical products that were useful only as intermediates in the production of other chemicals without known utilities were not patentable for lack of utility. In In re Joly, ${ }^{57}$ the court similarly held that chemical processes for generating the chemical intermediates for products without known utilities were also subject to patent rejection on the basis of lack of utility. However, these decisions were accompanied by Judge Rich's lengthy dissent in In re Kirk. ${ }^{58}$ This dissent remains one of the best exegeses of the utility requirement, as Judge Rich forcefully argued against extending the Manson holding beyond the facts of that case.

Perhaps in response to Judge Rich's dissent in In re Kirk, the PTO and the Federal Circuit have moved away from Manson's extreme and unequivocal holding. ${ }^{59}$ The standards governing the question of utility for pharmaceutical inventions have changed significantly over the past few years. ${ }^{60}$ The Federal Circuit's high rate of reversing PTO rejections of patents prompted the PTO to establish guidelines according to which PTO examiners consider applications for pharmacological inventions. ${ }^{61}$ The guidelines describe a more liberalized (that is, applicant friendly) standard for establishing utility of pharmacological inventions than the PTO used prior to this new standard. The guidelines address four types of evidence: human clinical trials, anmal trials (in vivo experiments), experiments done with cells grown in tissue culture (in vitro experiments), and structural data (similarity to compounds of known or suspected therapeutic value).$^{62}$ The guidelines note that "[i]n no case has a Federal court required an applicant to support an asserted utility with data from human clinical trials." ${ }^{163}$ In this way, the guidelines are careful

54. See id. at 531 n.17 ("[W]e express no view as to the patentability of a process whose sole demonstrated utility is to yield a product shown to inhibit the growth of tumors in laboratory animals.").

55. Manson, 383 U.S. at 536.

56. 376 F.2d 936 (C.C.P.A. 1967).

57. 376 F.2d 906 (C.C.P.A. 1967).

58. See 376 F.2d at 947-66 (Rich, J., dissenting).

59. The Supreme Court has not revisited the issue of utility since Manson, nor has Manson's holding on the issue of utility been superseded by congressional action. Thus, Manson technically remains good law on this point.

60. See PTO's Overview, supra note 26 , at $\S(\mathrm{I})$.

61. See id. $\S(\mathrm{III})$.

62. See id. § (III)(B)-(D).

63. Id. $\S(\mathrm{III})(\mathrm{C})$. 
to distinguish the PTO's mission in determining whether compounds have utility from the Food and Drug Administration's mission in ensuring that drugs offered for sale are both safe and effective. ${ }^{64}$ Nevertheless, the guidelines stop short of declaring that human clinical data will never be required, stating instead that in vitro and animal tests "almost invariably will be sufficient" to prove the utility of a pharmacological invention. ${ }^{65}$

The amount and strength of evidence necessary to prove that an invention is useful varies with the facts of each case. There must be a "reasonable correlation between the [evidence provided] and the asserted utility." 66 If the applicant establishes a reasonable correlation, then she need not "provide actual evidence of success in treating humans where such a utility is asserted." A "reasonable correlation" exists if the applicant's proffered in vivo or in vitro evidence "would be viewed by one skilled in the art as being reasonably predictive of the asserted utility. ${ }^{168}$ Thus, these pharmaceutical invention-specific guidelimes are an elaboration of, rather than a replacement for, the specific utility guidelines discussed, supra.

One would think that after Manson, ${ }^{69}$ In re Kirk, ${ }^{70}$ and In re Joly, ${ }^{71}$ the question of whether an applicant may use evidence of structural similarity of her claimed compounds (or the structural similarity of the compounds produced by her claimed process) to compounds of known or suspected therapeutic value would be answered decidedly in the negative. The guidelimes suggest otherwise. After notimg that "on several occasions" courts have found structural evidence to support an inventor's claim of specific utility, the guidelines admonish examiners to "give[] appropriate weight [to evidence of structural similarity to compounds of known therapeutic use] in determining whether one skilled in the art would find the asserted utility credible." ${ }^{.2}$ Interestingly, the guidelines make no mention of Manson.

At about the same time that the PTO was formulating its guidelines for assessing the specific utility of pharmaceutical imventions, the

64. See id. § (III)(D).

65. Id. § (III)(C) (emphasis added); see also § (III)(D) ("Examiners should not impose on applicants the unnecessary burden of providing evidence from human clinical trials.").

66. Id. § (III)(A).

67. Id.

68. Id. $\S(\mathrm{III})(\mathrm{C})$.

69. 383 U.S. 519 (1966); see supra notes $43-59$ and aecompanying text.

70. See note 56 and aecompanying text.

71. See note 57 and accompanying text.

72. PTO's Overview, supra note 26, at § (III)(B). For a critique of the PTO's "credible utility" requirement, see Andrew T. Kight, Pregnant with Ambiguity: Credibility and the PTO Utility Guidelines in Light of Brenner, 73 IND. L.J. 997 (1998). 
Federal Circuit considered the issue in In re Brana. ${ }^{73}$ The applicant in In re Brana claimed specific utility for a number of structurally related chemical compounds, asserting that they were superior as antitumor drugs to previously known, structurally similar compounds. ${ }^{74}$ One of these similar compounds was considered an excellent antitumor drug. ${ }^{75}$ The PTO rejected the applicant's patent, arguing both that the asserted utility was too vague and that the applicant failed to prove that the compounds had specific utility. ${ }^{76}$

The Federal Circuit rejected both of the PTO's arguments. ${ }^{77}$ The court held that the applicant's asserted utilities were not vague in light of the activity shown by the structurally similar compounds to which the applicant compared his compounds. ${ }^{78}$ The court also stated that the examiner bears the initial burden of establishing a prima facie case of nonutility and that the examiner failed to do so. ${ }^{79}$ Furthermore, even had the examiner established a prima facie case of nonutility, the applicant provided sufficient rebuttal evidence to overcome the examiner's decision. ${ }^{80}$ Thus, the Federal Circuit accepted the use of structural similarity as evidence that a compound has therapeutic utility. As with the PTO's guidelines, reference to Manson is conspicuously absent in In re Brana. ${ }^{81}$

The Supreme Court in Manson created the practical utility requirement as a barrier to the patenting of chemical inventions. It required an applicant to prove that her chemical invention was useful for something other than scientific research. Recently, both the Federal Circuit and the PTO have retreated from the practical utility standard. Each has adopted a utility requirement for pharmacological inventions that is more in line with the utility requirement for other types of inventions. The approach adopted by the PTO in its guidelines and by the Federal Circuit in In re Brana is a vast improvement over the Supreme

73. 51 F.3d 1560 (Fed. Cir. 1995).

74. See id. at 1562.

75. See id. at 1562-63.

76. See id. at 1563-64.

77. See id. at $1565,1566-68$.

78. See id. at $\mathbf{1 5 6 5 .}$

79. See id. at $\mathbf{1 5 6 6 .}$

80. See id. at 1566-67.

81. Commentators have castigated Manson more explicitly. See, e.g., 1 CHIsum, supra note 17, \$ 4.02[2][Cl; Hasan, supra note 43; Michelle L. Johnson, In re Brana and the Utility Examination Guidelines: A Light at the End of the Tunnel?, 49 RuTGERS L. Rev. 285 (1996); Phanesh Koneru, To Promote the Progress of Useful Article]s?: An Analysis of the Current Utility Standards of Pharmaceutical Products and Biotechnological Research Tools, 38 IDEA 625 (1998); Eric P. Mirabel, A Review of Recent Decisions of the United States Court of Appeals for the Federal Circuit: "Practical Utility" is a Useless Concept, 36 AM. U. L. Rev. 811 (1987); Brent Nelson Rushforth, The Patentability of Chemical Intermediates, 56 CALIF. L. Rev. 497 (1968); Timothy R. Howe, Comment, Patentability of Pioneering Pharmaceuticals: What's the Use?, 32 SAN DiEgo L. REv. 819 (1995). 
Court's arbitrary and rigidly dogmatic approach in Manson. It mitigates several of the problems with the current utility doctrine ${ }^{82}$ but it is far from perfect; the PTO guidelines contimue to penalize the most revolutionary pharmaceutical inventions. The person of ordinary skill in the art is unlikely to be convinced of the practical utility of the first treatment for a given disease without at least some clinical testing, if no satisfactory in vivo or in vitro models for the disease exist. On the contrary, the inventor of the hundredth treatment for a disease might well establish practical utility with very few in vitro data, even if the new drug is clearly inferior to other drugs already available to treat the disease. ${ }^{83}$

\section{General Utility}

Implicit in the requirement that a device have practical utility is the principle that the invention must be designed to address a problem or meet a need. This is the general utility requirement. For example, rolling sheet metal into tubes is a function with obvious industrial applications. Therefore, a PTO examiner would likely not question the general utility of such a device. General utility is a less dennanding requirement than specific utility. It provides almost no barrier to the patenting of inventions. Novelties, amusements, and games satisfy this requirement. ${ }^{84}$ Moreover, the invention need not be an improvement over the prior art. $^{85}$ The PTO will readily issue a patent on a less-than-revolutionary invention as long as the invention can be put to a valid use.

The threshold for general utility is so low that, in theory at least, it can be satisfied with only a nominal utility. ${ }^{86}$ For example, any composition with a density greater than air that can fit onto a desktop can be asserted to be useful as a paperweight (or, in the case of fluids or

82. See infra Section II.A.

83. See infra Part II.

84. The PTO has issued patents on games, novelties, and amusements that run the gamut from the traditional (see, e.g., U.S. Pat. No. 5,673,813, Candy-Dispensing Device), to the educational (see, e.g., U.S. Pat. No. 4,373,918, Audio-Visual, Child-Participating Educational Entertainment Center), to the strange (see, e.g., U.S. Pat. No. 5,683,314, Water Activated Hopscotch Game; U.S. Pat. No. 5,522,507, Kit for Enacting the Tooth Fairy Fable), to the sinister (see, e.g., U.S. Pat. No. 4,834,657, Punishment Wheel (a sort of "Wheel of Misfortune" for children, enabling their parents to inflict randomly selected purishments on them)).

85. Judge Story rejected the requirement of superiority to the prior art more than 180 years ago:

[The defendant] contends, that it is necessary for the plaintiff to prove, that his invention is of general utility; so that in fact, for the ordinary purposes of life, it must supersede the pumps in common use. In short, that it must be, for the public, a better pump than the common pump.... I do not so understand the law.

Lowell v. Lewis, 15 F. Cas. 1018, 1019 (D. Mass. 1817).

86. See In re Kirk, 376 F.2d 936, 961 (1967) (Rich, J., dissenting) (criticizing the majority opinion as encouraging "scarce scientific and inventive brainpower to waste its time concocting 'legal utilities' ...'). Although nominal utility presents serious challenges to the patent law's doctrine of utility, inventors have a strong incentive to avoid reliance on nominal utility whenever possible. See MERGES, supra note 1, at 219. 
powders, asserted to be useful as a paperweight filler). Any gas with a density less than air can be claimed for its use in filling lighter-than-air balloons, no matter how expensive, toxic, flammable, or otherwise inferior to helium it may be.

In most cases, inventors avoid claiming nominal utility as a substitute for substantive utility. Patenting a composition under a nominal utility allows another inventor to patent any more substantive use of that same composition ${ }^{87}$ If that happens, for either inventor to practice the process, the parties must reach a licensing agreement. ${ }^{88}$ In such a case, the original inventor will have to share the profits generated by the process with the inventor of the process. Had the composition's inventor successfully pursued the invention of the process herself, she could have patented both the composition and the process. Accordingly, she would not then have to share the profits of the process, nor negotiate a licensing agreement, with the other inventor.

That being said, circumstances exist under which an inventor has a strong incentive to patent a composition by citing nominal utilities. The current controversy surrounding the patenting of expressed sequence tags (ESTs) presents such a situation. ${ }^{89}$ ESTs are fragments of human genes. It is well established that human genes and other DNA sequences comprise patentable subject matter. ${ }^{90}$ Typically, human genes are claimed to be useful in treating a particular condition or disease, the study of which led to the isolation of the gene. ${ }^{91}$ ESTs, however, are different from conventionally isolated genes in several important ways. First, their method of isolation provides very little clue as to the processes in which they are involved, much less their precise roles within that process. Second, they are harvested somewhat randomly and en masse. This allows the process to be highly automated. Thus, ESTs are much cheaper to isolate than conventionally isolated genes. Third, because they are isolated relatively randomly, a very small fraction of ESTs will likely ever be found useful in treating human disease. Fourth, the effort and cost of finding a substantial use for a given EST (even assuming that such a use can be found) is likely to be enormous. Fifth, the very

87. In fact, a new use for any prior art invention may be patented as a process, regardless of whether the prior art invention was patented under a nominal or substantial utility. See 35 U.S.C. $\S$ I00(b) (1994); Rohm \& Haas Co. v. Roberts Chem. Inc., 245 F.2d 693 (4th Cir. I957).

88. See generally Robert P. Merges \& Richard R. Nelson, On the Complex Economics of Patent Scope, 90 Colum. L. REv. 839, 860-68 (1990) (explaining the economic forces at work between holders of such "blocking patents").

89. See generally Rebecca S. Eisenberg \& Robert P. Merges, Opinion Letter as to the Patentability of Certain Inventions Associated with the Identification of Partial cDNA Sequences, 23 AIPLA Q. J. 1, 13-20 (1995) (analyzing the utility of ESTs).

90. See, e.g., U.S. Pat. No. 5,824,794, Human Stromelysin-1 Promoter; see also MERges, supra note 1 , at $160-6 \mathrm{I}$.

91. See, e.g., U.S. Pat. No. 5,824,794, Human Stromelysin-1 Promoter. 
small fraction of ESTs that will be useful for discovering treatments for diseases will likely generate immense profits. ${ }^{92}$

This unique combination of factors creates a strong incentive for an inventor to patent as many ESTs as possible using nominal utilities. The more ESTs she has patented, the more likely it is that a subsequent inventor will discover that the disease treatment he is working on requires that he use one of the first inventor's ESTs. ${ }^{93}$ The first inventor's EST patent will allow her to bargain with the second inventor for a profit disproportionately in excess to the effort and money she invested in isolatimg her collection of ESTs.

In spite of nearly unanimous criticism from the legal and scientific communities, ${ }^{94}$ the PTO supports the patenting of ESTs based on what are arguably nominal utilities. ${ }^{95}$ In the coming years, these patents surely will be challenged in court. Thus, their ultimate validity is in doubt. ${ }^{96}$

\section{Moral Utility}

Moral utility is a particular formulation of the general utility requirement. Its origms lie in dictum in Lowell $v$. Lewis. ${ }^{97}$ After dispatching with the notion that the patent laws require each patented invention to be superior to the prior art, Judge Story propounded his own interpretation of the utility requirement. According to Judge Story, the utility requirement exists only to protect the public froin harm:

All that the law requires is, that the invention should not be frivolous or injurious to the well-being, good policy, or sound morals of society. The word "useful," therefore, is incorporated into the act in contradistinction to mischievous or immoral. For instance, a new invention to poison people, or to promote

92. See generally Bruce Alberts et al., Molecular Biology of the Cell 308-18 (3d ed. 1994) (describing conventional techniques of isolating genes); Leslie Roberts, Gambling on a Shortcut to Genome Sequencing, 252 ScI. 1618 (1991) (describing new technique for isolating ESTs).

93. See F-D-C Reports, Gene Fragment Patents May Preempt Full Gene Patent in Certain Cases, PTO Says; PTO Urging Full Enablement Disclosure After Genentech v. Novo Nordisk, 59 Pinksheet, June 16, 1997, available in 1997 WL 16952843.

94. See Eisenberg \& Merges, supra note 89; Leslie Roberts, Genome Patent Fight Erupts, 254 Scr. 184 (1991); F-D-C Reports, PTO Decision to Allow Gene Fragment Patents Is “Appalling," $U$. Washington's Hood Tells AAAS, PTO Official Says Issue Is "Obviousness," Not "Utility" of ESTs, 59 Pinksheet, Feb. 24, 1997, available in 1997 WL 16952029. But see Scott A. Chambers, Comments on the Patentability of Certain Inventions Associated with the Identification of Partial cDNA Sequences, 23 AIPLA Q.J. 53 (1996) (defending EST patents).

95. See Ed Susman, U.S. PTO to Allow Patents on Gene Fragments Called ESTs, BiотеCH Newswatch 1, Mar. 3, 1997, available in 1997 WL 8790500; Lynn Pasahow \& Andrew Kumamoto, Human Genome Project Raises Patenting Issues: Debate Focuses on Patentability of Expressed Sequence Tags-Certain Partial DNA Sequences, NAT'L L. J., Oct. 20, 1997, at C31.

96. The prospective utility formulation proposed in this Comment, see infra Part II, obviates the rigid "all or none" patentability of ESTs under nominal utilities, replacing it with an approach that would examine the future likely use of each individual EST.

97. 15 F. Cas. 1018, 1019 (D. Mass. 1817). 
debauchery, or to facilitate private assassination, is not a patentable invention. ${ }^{98}$

As this doctrine developed in the case law, the "harms" from which it protected the public were largely subjective moral ones. ${ }^{99}$ As Victorian attitudes fell from favor, so too did the moral utility doctrine. ${ }^{100}$ This is in some ways unfortunate. Judicial misinterpretation of Judge Story's insightful articulation of the utility requirement as shrill moralizing obscures his real message which is that the marketplace is the ultimate arbiter of an invention's utility. ${ }^{101}$

\section{E. The Utility Requirement: Reality and Potential}

As seen above, the utility doctrine usually has been a low hurdle for patent applicants to clear. It became lower still with the waning of the moral utility doctrine. In Manson the utility doctrine erupted from its dormancy, ${ }^{102}$ but became less significant as the PTO and the courts returned to an applicant-friendly standard. Because the current utility requirements are easily satisfied, they are rarely litigated. Because utility is rarely litigated, insufficient attention has been paid to the purpose of the utility requirement.

Poorly reasoned decisions, such as Manson, are the inevitable result when the goals and policies underlying black letter law are unclear. Questionable decisions by appellate courts, in turn, tempt lower courts and administrative agencies to limit those decisions to their facts and strike off on their own in search of better tests and rules. Such an outcome not only blurs the line separating what is patentable from what is not, it robs the patent law of two of the most valuable attributes of any area of law-consistency and predictability. ${ }^{103}$

In an attempt to right these problems, and restore the attributes of clarity, consistency, and predictability to patent law, this Comment proposes a new approach to utility. That approach is defined and examined in the next two Parts.

98. Id.

99. See, e.g., National Automatic Device Co. v. Lloyd, 40 F. 89 (N.D. Ill. 1889) (invalidating patent for toy race horse game held to be useful only to drunken gamblers); Schultze v. Holtz, $82 \mathrm{~F}$. 448 (N.D. Cal. 1897) (holding that there is "certainly no utility" in a gambling machine); Brewer v. Lichtenstein, 278 F. 512 (7th Cir. 1922) (holding that the accused device was useful only for illegal lotteries and therefore invalidating its patent).

100. See, e.g., Koppe v. Burnstingle 29 F.2d 923 (D.R.I. 1929) (upholding patent on game that had both legal and illegal uses); accord Callison v. Dean 70 F.2d 55 (10th Cir. 1934); Chicago Patent Corp. v. Genco, Inc., 124 F.2d 725 (7th Cir. 1941).

101. See Lowell, 15 F. Cas. at 1019 ("If [the invention] be not extensively useful, it will silently sink into contempt and disregard.").

102. See supra notes $43-59$ and accompanying text.

103. Cf. Oliver Wendell Holmes JR., The Common Law 79 (1881) "The business of the law of torts is to fix the dividing lines between those cases in which a man is liable for harm which he has done, and those in which he is not."). 
II

Formulating a New Definition of Utility

The utility requirement's checkered past and uncertain future, as described in Part I, bespeaks fundamental problems with the current utility doctrine. This Part of this Comment identifies those problems. It next proposes a new formulation of the utility requirement-based on the probability that a claimed invention will be truly useful-that resolves these identified problems.

\section{A. Problems with the Current Utility Doctrine}

\section{Tension with the Constitution}

As seen above, the current utility doctrine is grounded in three sources: ${ }^{104}$ (1) the Constitution's language that Congress may promote the progress of the useful arts; ${ }^{105}$ (2) Congress's implementation of that constitutional mandate in the language of section 101 of the Patent Act which requires each patented invention to be useful; ${ }^{106}$ and (3) court decisions, particularly those of the Supreme Court and the Federal Circuit (and its predecessor, the C.C.P.A.), interpreting the meaning of the word "useful.".107

Most courts have assumed that the meaning of "useful" in section 101 of the Patent Act is identical to the meaning of the underlying constitutional language. A more sophisticated reading of the Constitution and the Patent Act, however, reveals a tension between the two. The Constitution focuses on the "Arts," the industries and other fields of endeavor that the patent law serves. According to this interpretation, the goal of the patent law is to shepherd the progress of commercial fields (e.g., mechanical engineering, biotechnology, amusements, etc.). It is a big picture, or "macro," view of patent law.

This is at odds with the courts' interpretation of the language used in section 101 of the Patent Act. Section 101 allows patents to issue to only those inventions that are "useful." 108 In contrast with the language of the Constitution, the focus im the Patent Act is on the individual

104. A fourth source, the PTO, might also be added to this list, but its posture in patent examinations, hearings before its Board of Appeals, and its guidelines for examiners, has been one of deference to the courts. See, e.g., U.S. Patent and Trademark Office, PTO's Examiner Guidelines for Biotech Applications, 49 PAT. TRADEMARK \& Copyright J. 234, 241 ("The Federal courts have consistently reversed rejections by the [PTO] asserting a lack of utility under $\$ 101$ for inventions claiming a pharmacological or therapeutic utility.... In view of this, Examiners should be particularly careful in their review of evidence provided in support of an asserted therapeutic or pharmacological utility.").

105. See supra note 10 and accompanying text.

106. See supra notes 5, 11-17 and accompanying text.

107. See supra Part $\mathrm{I}$.

108. See 35 U.S.C. § 101 (1994). 
invention. Section 101 of the Patent Act, then, presents the "micro" view of the utility requirement. According to this interpretation, patent monopolies are inherently valuable to the patentee and, conversely, inherently costly to society. The purpose of the utility requirement is to protect zealously society's precious monopoly rights from being squandered on useless inventions.

\section{Illusory Benefits of the Current Utility Doctrine}

Another weakness of the current utility doctrine is that two of its alleged benefits are in fact illusory. First, the current utility requirement ensures that useless inventions are not granted patent protection. The present value of an invention without a current or foreseeable use is nothing. Correspondingly, there is no worth in the right to exclude others from making, using, selling, or importing an invention (that is, the right conferred by a patent) ${ }^{109}$ that is worthless. The current utility doctrine, therefore, protects society from monopolies on useless inventions when no harm accompanies that monopoly. ${ }^{110}$ Ironically, the current utility doctrine provides feeble protection from the phantom harm of worthless monopolies, for it is defeated by mere nominal utility."11

Another illusory benefit of the current utility doctrine is that it rejects patents that allow the patentee to leverage an insigmificant invention mto domination of a useful field or industry. The rights granted by a patent make this possible. As explained previously, ${ }^{12}$ a patent confers on the patentee the right to exclude others from practicing the patented invention, but not the right to practice it herself. The patentee may be blocked from practicing her own invention by someone else's patent. The blocking patent can confer on its holder rewards (in the form of licensing fees from the other patentee) greatly in excess of the value of the blocking patent's invention's actual worth. Or, the holder of the blocking patent could refuse to deal at all, and so retard the growth or progress of a useful industry.

According to Manson, ${ }^{113}$ the utility requirement prevents this problem by denying patent protection to useless imventions, which might later mature into blocking patents. ${ }^{114}$ This argument proves too much because it applies to every patented composition of matter, whether or

109. See 35 U.S.C. § 154(a)(1) (1994).

110. Moreover, the Patent Act provides a much simpler mechanism for discouraging "worthless" patents: the cost of prosecuting a patent application. This cost includes the fees charged by the PTO (see 35 U.S.C. $\$ 41$ (1994)), attorneys' fees, and opportumity costs. An applicant easily can spend thousands of dollars securing a "worthless" patent.

111. See supra notes $87-95$ and accompanying text.

112. See id.

113. See Brenner v. Manson, 383 U.S. 519, 534-35 (1966).

114. See $i d$. at 536 ("[A] patent is not a hunting hicense."). 
not its inventor knows of a use for it when it is patented. A more significant and lucrative use might be found for any invention, not just currently "useless" ones. Today's finger paint may be tomorrow's miracle drug. The logical conclusion of this argument is that patents should never be granted lest another, better use for the invention subsequently be discovered. But that is precisely the result that the patent law encourages. The more uses that are found for an invention, and the more valuable they are, the greater the benefit that inures to society. ${ }^{115}$

\section{Inefficiency}

Worse, the meffectiveness of the current utility doctrine comes at no small price. As the apothegm goes, "If you never miss a flight, then you are spending too much time at airports." In other words, maximum benefit is not always optimal benefit. Demanding current utility from each invention is like never missing a flight: success requires an inefficient expenditure of resources. Just as the business traveler's goal ought to be the most productive use of her time (which entails a risk that she will occasionally miss a flight), so, too, ought the utility requirement's goal be to promote the greatest progress of the useful arts (which entails a risk that occasionally a patent will be issued for a truly useless invention).

The progress of the useful arts is harmed by punctiliously assuring that each invention is supported by a utility in its present form. Each patented invention, useless or otherwise, becomes public knowledge. That knowledge becomes available to all who would find a use for it. That the publication of issued patents is a public good is a foundation of American patent law. ${ }^{116}$ If an invention is not patented, it remains a secret known only to the inventor. It is probably fair to assume that the more knowledge that is available to the art, the more progress it will realize.

\section{Shortsightedness}

The current utility doctrine is also shortsighted. It demands that a patentable invention have a well-defined use at the time the inventor files her patent application. If this condition is not met, the PTO or

115. This analysis arguably breaks down where a patentee is able to patent cheaply an invention that she knows is likely to be found valuable later, through the efforts of another party. The original inventor can then charge a licensing fee disproportionately in excess of her contribution to the value of the invention. This situation is analogous to the current controversy surrounding the patentability of ESTs. See supra notes $87-95$ and accompanying text.

116. See Manson, 383 U.S. at 533 ("[O]ne of the purposes of the patent system is to encourage dissemination of information concerning discoveries and inventions."); In re Kirk, 376 F.2d 936, 963 (1967) (Rich, J., dissenting) (dccrying the majority opinion as "disrupt[ing] the smooth operation of our incentive system by delaying disclosure of new [inventions] ..."). 
appellate judge will deny or invalidate the patent. Without patent protection, the creator of an invention without a present use will labor in secret to find a use-any use - that will allow her to patent her invention. The use she finds may be a trivial subset of the uses to which her invention could profitably be put (for she may claim her invention under a nominal utility). ${ }^{117}$ Worse yet, she may abandon her research, thereby depriving society of her work until someone else independently invents it and finds a use for it. Such a result is both inefficient and detrimental to scientific progress. Ironically, some revolutionary inventions will be among the most likely to languish unnecessarily in obscurity because their specific utility will be hardest to establish. The scope of this problem will be difficult to determine because these inventions will suffer anonymous deaths. This problem is likely to be most acute in the chemical, biochemical, and pharmacological fields where each new invention has an almost infinite number of potential uses. Testing a significant fraction of those uses may be beyond the power of even the most sophisticated and well-funded industrial patent assignee. Therefore, a new understanding of the utility requirement is required.

\section{B. A New Formula for Determining Utility}

This Comment proposes the doctrine of "prospective utility" as a new standard for determining whether an invention has utility. Prospective utility is grounded in three precepts. First, section 101 of the Patent Act must be interpreted consistently with the language of the Constitution. The primary goal of patent law must be the progress of the useful arts. Second, the word "useful" in section 101 should be interpreted reasonably. Third, and less obviously, there is a variety of socalled useless inventions. Under the current utility doctrine, useless inventions include inventions that are truly hopeless as well as inventions that clearly will be useful in the near future.

The current specific utility requirement, as explained above, inefficiently promotes the progress of the useful arts by insisting that each patented invention be useful in its current form. One solution to this problem is to do away entirely with the utility requirement. Another solution is to declare that certain classes of inventions have utility per se. ${ }^{118}$ This idea might well have merit, but it lies exclusively within the domain of Congress to enact it. ${ }^{119}$ A more modest version of the same

117. See supra notes $87-95$ and accompanying text.

118. See Koneru, supra note 81 , at $667-68$.

119. Section 101's "useful" language is arguably in tension with the Constitution. See stupra discussion at Section II.A.1. Perhaps on that basis a litigant could challenge the constitutionality of the current utility doctrine. However, the issue may be nonjusticiable in that the power to determine how best to promote the progress of the useful arts is reserved exclusively to Congress. $C f$. Nixon v. United 
idea is to revert to Judge Story's elegant definition of utility. ${ }^{120}$ That option, while appealing, is probably foreclosed by the current version of the Patent Act, which requires that each patented invention be useful. ${ }^{121}$ To adopt Judge Story's definition under the current Patent Act, we must define "useful" as "not frivolous or injurious." As the Supreme Court held in Brenner v. Manson, ${ }^{122}$ to do so would stretch the definition of useful beyond recognition in violation of the view argued in this Comment that section 101's useful requirenent should be interpreted reasonably.

Prospective utility is consistent with the precepts of constitutional coordination, reasonable interpretation, and a reasonable definition of useless. It also includes a factor that is overlooked by current doctrinethe probability that an invention will someday be useful. Under the prospective utility doctrine proposed here, useful is interpreted as meaning having utility at present, or having a reasonable chance of being reasonably useful in the foreseeable future.

Under this definition, the usefulness of an invention can be expressed as the product of two numerical factors: the probability that soineone will develop a reasonably valuable use for the invention in the foreseeable future expressed as a number between 0 (no foreseeable future use) and 1 (certainty of future use; i.e., present usefulness) and the magnitude or degree of that usefulness. Thus, the magnitude of the potential usefulness of an invention is discounted by the probability that the usefulness will never be realized. Under current utility doctrine, the law requires a $100 \%$ probability (i.e., present existence) of at least a trivial degree of usefulness (e.g., nominal or nearly nominal utility). ${ }^{123}$ Expressed in this way, the capricious nature of the current definition of utility is apparent. Present nominal utility is exalted over eventual significant utility at the expense of the progress of the useful arts.

States, 506 U.S. 224 (1993) (holding Congress's constitutionally granted power of impeachment beyond judicial review).

120. See supra note 98 and accompanying text.

121. See 35 U.S.C. $\S 101$ (1994) ("Whoever invents ... any new and useful [invention] may obtain a patent therefore. ...").

122. 383 U.S. 519,533 (1966) (holding that interpreting "useful" as meaning "not positively harmful... places such a special meaning on the word 'useful' that we cannot accept it in the absence of evidence that Congress so intended").

123. In fact, current utility doctrine does allow for a limited showing of a possibility of future specific utility. As discussed above, the PTO's new guidelmes for examining the utility of pharmaceutical inventions, see PTO's Overview, supra note 26; and the Federal Circuit's holding in In re Brana, 51 F.3d 1560 (Fed. Cir. 1995), allow the applicant to establish utility based on the likelihood that structural homology, in vitro, or in vivo tests predict effectiveness in humans. See also Fujikawa v. Wattanasin, 93 F.3d 1559, 1564 (Fed. Cir. 1996) ("[T]here must be a sufficient correlation between the tests and an asserted pharmacological activity so as to convince those skilled in the art, to a reasonable probability, that the novel compound will exhibit the asserted pharmacological behavior."). 
The point of this formula is not to generate two numbers, one for probability, the other for magnitude, multiply them, and compare their product to a reference number to determine unequivocally whether the claimed invention meets the legal standard of utility. ${ }^{124}$ Rather, the formula should be thought of like other similar formulae used by the courts. For example, the Supreme Court has endorsed a definition of materiality of information for insider trading violations of section 10b-5 of the Securities Exchange Act of 1934. ${ }^{125}$ That definition relies on a similar formula - probability of the occurrence of an event multiplied by the nuagnitude of the importance of the event to the corporation. ${ }^{126}$ Yet neither the Supreme Court nor any lower court employing the formula-including the Second Circuit, which first used it-has ever used the formula literally to generate a number dispositive to the issue. Rather, the purpose of these formulae is to focus the fact finder's attention on the relevant issues and to offer guidance as to how they are to be weighed.

It is important to recognize at the outset that the application of this new utility formula will inevitably result in the issuance of a few patents to inventions that never will become useful, at least not within the life of their patents. These are akin to the missed flights in the airport illustration discussed, supra. Success or failure is not determined at the micro level of a single patent, but rather at the macro level of the progress of the useful arts. The goal of the utility requirement should not be to make it impossible to patent a useless invention, but rather to promote the optimal progress of the useful arts.

\section{III}

\section{ApPlying the Prospective Utility Formula}

\section{A. Determining Probability}

The first step in applying the prospective utility formula is to determine the probability that the invention will be found useful in the foreseeable future. This elentent of the formula is akin to specific utility. A high probability score means that an invention is likely to be functional. A low probability score means that an invention is unlikely to be functional. One cannot peer into the future to determine whether an invention will eventually prove useful. The PTO and the courts are limited to working with currently available information regarding a patent's usefulness. Courts, however, frequently determine the probability

124. Cf. Moison v. Loftus, 178 F.2d 148, 149 (2d Cir. 1949) ("[A]ll such attempts [to reduce the question of negligence to an algebraic formulal are illusory; and, if serviccable at all, are so only to center attention upon which one of the factors may be determinative in any given situation.").

125. 17 C.F.R. § 240.10b-5 (1997).

126. See Basic Inc. v. Levinson, 485 U.S. 224 (1988). 
that a given event will occur. In fact, they often must make such determinations after the fact, when the possibility of being blinded by hindsight is acute.

For example, in applying the celebrated Hand formula ${ }^{127}$ in a negligence case, a court must determine the probability that the harm in question would happen after the harm in question has already happened. The court must, ex post, attempt to disregard the fact that the harm in question did in fact occur. ${ }^{128}$ If it does not, then the trial will be biased against the defendant. The application of a formula to determine the future utility of an invention is less likely to be biased because the probability of a future event is at issue. Thus, the actual outcome-that is, whether the invention is or is not eventually found useful-cannot bias the PTO or the courts' ex ante determination of the probability that the invention will be found useful.

Even if unbiased, determination of the probability of a future event is not necessarily easy. Yet the application of a few guiding principles will ensure that the process helps to further the policies of the patent law. The goal of the prospective utility doctrine is to apply the utility requirement fairly and consistently from case to case, so far as is possible, in accordance with the requirements of the Constitution and the Patent Act.

\section{Inventions with Current Utility}

The ultimate showing that an invention will have a utility im the foreseeable future is that it has a demonstrable utility at the time of the patent application. This is the current requirement for satisfaction of the utility requirement. Under the prospective utility formula, present utility likely would endure as the most common method chosen to patent inventions because it virtually ensures success. As discussed below in Section III.B., "Determining Utility," a probability of one (on a scale of zero to one) is sufficient for inventions with all but the most meager of magnitudes of utility.

\section{Inventions Without Current Utility}

For inventions without presently demonstrated utility, the current utility doctrine defeats the patent application. In contrast, the prospective utility doctrine would compare the invention to other similar inventions, if such inventions exist. If such a comparison results in a high

127. See United States v. Carroll Towing Co., 159 F.2d 169, 173 (2d Cir. 1947) (describing a formula for determining whether defendant's behavior was negligent where the magnitude of the harm is discounted by the probability that it would not have occurred, and the product compared to the defendant's cost of preventing the harm).

128. This simplified discussion assumes that the plaintiff has proved it suffered harm. 
probability of future utility, the PTO should patent the presently useless invention on the theory that the invention is likely to become useful in the future. The key to the success of prospective utility rests in the ability of applicants and PTO examiners to identify correctly the relevant class of inventions against which to compare the applicant's presently useless invention.

\section{a. New Species Within Known Genera}

Many, if not most, new inventions share substantial similarities with some class of inventions already in existence. Accordingly, these new inventions can be thought of as new species within old genera. ${ }^{129}$ The genus provides the fact finder with a large or small number of inventions whose utilities can be used to calculate the probability that the claimed invention will be found useful. For example, imagine a class of chemical compounds that share a structural feature. Of these compounds, $45 \%$ are known to be useful in reducing swelling in injured tissue. If the claimed compound also contains the structural feature, then the probability of the claimed compound having a utility in the foreseeable future is 0.45 .

Several points in this highly simplified example require closer scrutiny. First, how does one determine what the appropriate genus is? In the given example, it was stipulated that the compounds all shared a similar structural feature. One might worry that an applicant would be tempted to define the relevant genus so as to maximize the number of species of known utility that it contains, so as to maximize the probability score. The applicant should do precisely that. The PTO should accord the applicant broad discretion in defining the relevant genus because the applicant has the greatest knowledge about her invention and its relation to other discoveries in her field. The court or examiner should accept any genus that would be acceptable to a person of ordinary skill in the art. In other words, the applicant ought to be allowed to use all reasonable criteria to determine which species are included in the reference genus. In the given example, the applicant might reasonably exclude a number of compounds that would otherwise fall within the genus because they contain an additional chemical group which the claimed compound lacks. Of course, the examiner or court will have to guard against the applicant including in the reference genus inventions

129. The use of the terms "species", "genus", and "genera" in this context is similar to their use in the context of determining (1) nonobviousness, see In re Baird, 16 F.3d 380 (Fed Cir. 1994) (addressing the question of whether a generic formula in the prior art renders obvious every species of compound it can produce); and (2) enablement, see Amgen, lnc. v. Chugai Pharm. Co., Ltd., 927 F.2d 1200 (Fed. Cir. 1991) (considering whether a claim to a generic DNA sequence enables each specific DNA sequence it encompasses). These two requirements are discussed supra notes 8-9 and accompanying text. 
with known utilities but with less similarity to the claimed invention, while excluding inventions without known utilities but with greater similarity to the claimed invention..$^{130}$

Second, how does one determine the probability of a utility being discovered for an invention when the relevant genus contains species with varying degrees of utility? For example, imagine the claimed invention is intended for use to reduce fever. The reference genus consists of species of which $10 \%$ were shown to be effective in clinical trials, $25 \%$ were shown effective in animal models, and $30 \%$ have shown promise in in vitro tests. The remaining $35 \%$ failed to show any effectiveness at all. In the simplest version of this scenario, each of the species in the reference genus has been tested fully in vitro, in vivo, and in clinical trials. We know that there is a $10 \%$ chance that the members of this genus (which now includes the claimed compound) will be useful in treatimg fever in a climical setting.

A more interesting-and more realistic-version of this scenario would involve greater complications. For example, of the $10 \%$ of species that are effective in humans, only half umght be effective in the in vitro test. Of the $25 \%$ that were effective in animals, most may not yet have been tested in humans. And many of the $30 \%$ that showed success in vitro may not have been tried yet in animals or humans. How is one to combine these probabilities into a single number meant to give an accurate reflection of the probability that the claimed invention will be useful? Significantly, $10 \%$ is still the baseline. The practical utility of this portion of the genus clearly has been established. The only question is how one weighs the remaining members of this genus. It is worth reiterating at this point that this inquiry is not necessarily designed to generate an actual numerical value for the probability of the claimed invention having utility, but rather to focus the fact finder's attention on the relevant issues and to accord each concern an appropriate weight relative to the other concerns.

\section{b. New Species Within New Genera: Commercial Success as an Indication of Utility}

Under current patent law, a new invention without similarity to any known useful invention and with no known present use is not patentable. Under the system of prospective utility proposed here, it will still be difficult for the inventor to make a compelling case for her

130. Such devious behavior should be considered prima facie evidence of inequitable conduct. Defendants may use plaintiffs' inequitable conduct in procuring a patent as a defense to infringement. A finding of inequitable conduct renders a patent unenforceable. See, e.g., Baxter lnt'l, Inc. v. McGaw, Inc., 149 F.3d 1321 (Fed. Cir. 1998) (explaining and applying the requirements for a finding of inequitable conduct). 
invention's utility, but she will at least have a chance to make an argument to the PTO examiner. Her invention most probably will not be useful in the foreseeable future, but there is a small chance that it will be of revolutionary importance.

How will an inventor make a case that her unprecedented invention will be found useful in the foreseeable future? She might argue that her invention is useful because others have paid her money for it. She might also argue that her invention is similar to other inventions that have been sold. Judge Story, in Lowell v. Lewis, propounded a similar theory when he wrote that the only ground for rejection of an application for lack of utility was that the invention lacked moral utility. ${ }^{131}$ According to Judge Story, whether an invention is or is not truly useful is a matter for the market to decide. What Judge Story did not acknowledge is that some inventions are tested by the market before a patent application is filed. ${ }^{132}$ In such instances, the courts do not have to predict whether an invention will have utility. Courts deciding patent infringement suits, however, are frequently called upon to judge the success of inventions in the marketplace. Commercial success has developed into an important consideration in infringement cases where the invention is attacked by the defendant as being obvious. ${ }^{133}$

For market success to be a reliable index of the nonobviousness of an invention, it must be tied to the attributes of the invention as described in the application's claims. Market success is influenced by a number of factors. ${ }^{134}$ Some of those factors are unrelated to the invention per se. The applicant must show a nexus between the market success of the invention and the claims of the application. Commentators have criticized using market success as an indication of an invention's nonobviousness. ${ }^{135}$ They argue that commercial success is tenuously related, at best, to the issue of whether one of ordinary skill in the art would have found the invention nonobvious. But the connection between commercial success and utility is much more direct. True, some of the same pitfalls must be avoided. The fact finder must carefully

131. 15 F. Cas. 1018, 1019 (D. Mass. 1817) ("If [the invention] be not extensively useful, it will silently sink into contempt and disregard."); see also supra notes 97-101 and accompanying text.

132. The inventor may license her unpatented invention as a trade secret, but she must file a patent application within one year of the licensing, or she will be barred from ever filing. See 35 U.S.C. $\$ 102$ (b) (1994). That period may be extended if the inventor can establish that the licensing was for a necessary "experimental use." See Elizabeth v. Pavement Co., 97 U.S. 126 (1877).

133. See, e.g., Graham v. John Deere Co., 383 U.S. 1, 17-18 (1966) (listing commercial success as a "secondary consideration" of nonobviousness); Hybritech Inc. v. Monoclonal Antibodies, Inc., 802 F.2d 1367, 1380-84 (Fed. Cir. 1986) (examining the commercial success of an invention as an "objective" indicium of nonobviousness).

134. See Robert P. Merges, Commercial Success and Patent Standards: Economic Perspectives on Innovation, 76 CALIF. L. REv. 805, 826-27 (1988).

135. See, e.g., id. at $838-46$. 
identify those elements of the invention's market success unrelated to its inherent utility and remove them from the analysis.

However, there is an important difference between the nonobviousness market test and the utility market test proposed in the prospective utility doctrine. The product must do very well in the marketplace for this factor to indicate nonobviousness. ${ }^{136} \mathrm{~A}$ similar level of success is too much to ask of an invention for purposes of establishing utility. The minimum level of market success required to prove utility is a difficult question to determine because it touches on fundamental aspects of the utility requirement which courts very rarely consider. When we say that an invention has utility, we say that it is useful, but without specifying how useful, and to whom, or for what. ${ }^{137}$ An invention does not have to be very useful in order for it to be patented, ${ }^{138}$ nouminal utility will suffice. More useful inventions will tend to be in greater demand. The greater the demand for an invention, the more the inventor can charge for the invention on the open market. The other questions regarding to whom an invention must be useful, and for what, are closely related. They are considered in Section III.B., infra.

One might argue that a market-based approach to determining an mvention's utility is too lenient. It will allow inventions to be found useful merely because someone is willing to pay for them without any regard to whether they have specific or general utility. In fact, the greater danger is that the test will be applied too stringently. Many patented inventions fail in the marketplace, if they make it out of the laboratory at all. As Judge Story observed in Lowell, the law does not require an invention to be better for its intended use than all other existing inventions. ${ }^{139}$ Markedly inferior inventions may still possess the requisite degree of usefulness demanded by the utility requirement. Thus, market failure should never be allowed as an argument against an invention's utility.

Currently, there is a general misunderstanding of the relationship between commercial success and utility. Different courts have made different pronouncements on the subject. For example, in Studiengesellschaft Kohle v. Eastman Kodak, the Fifth Circuit held that "[t]o require the product to be the victor in the competition of the marketplace is to impose upon patentees a burden far beyond that expressed in the statute." 140 The court in Imperial Chemical Industries $v$. Henkel found that "commercial success is not the standard of

136. See, e.g., Hybritech, 802 F.2d. at 1382 (finding that patented invention's dominance in crowded market established utility).

137. See In re Kirk, 376 F.2d 936, 949 (C.C.P.A. 1967) (Rich, J., dissenting).

138. See supra notes $87-95$ and accompanying text.

139. See 15 F. Cas. 1018,1019 (D. Mass. 1817).

140. 616 F.2d 1315, 1339 (5th Cir. 1980). 
usefulness under the Patent Act." 141 Judge Story apparently meant much the same thing when he held in Lowell that "whether [the invention] be more or less useful is a circumstance very material to the interests of the patentee, but of no importance to the public. If it be not extensively useful, it will silently sink into contempt and disregard."142 Taken together, the courts seem to be in agreement that commercial success is not germane to determining whether an invention has utility.

More carefully parsed, however, a different interpretation emerges from the case law. The statement from Studiengesellschaft says only that commercial success is not a requirement for patentability. It is difficult to.imagine a patent system that would impose so burdensome a requirement. Imperial Chemical and Lowell simply point out that the utility requirement is not identical to commercial success. It is a mistake to read these statements as repudiations of the relationship between utility and commercial success. A more accurate interpretation, and one more in line with the purpose and scope of the utility requirement, is that utility and commercial success are related, but not identical. A product's success in the market place is due to one or more factors such as advertising, marketing, reputation, distribution, etc. One of these factors is the utility of the product - that is, its amenability to being used by consumers to achieve a goal, such as removing stains, amusing children, or transferring data. In fact, one might argue that an absolute requirement for a product to succeed in the market is that it not be totally useless. Thus, a better understanding of Studiengesellschaft, Imperial Chemical, and Lowell is that commercial success is related to utility in that the former is dependent on the latter. Evidence of commercial success will frequently provide evidence of utility, but commercial failure will never be evidence of a lack of utility.

At first, this inquiry into the probability of usefulness appears heretical. Probability does not fit well with our understanding of patent law as derived from contract law. ${ }^{143}$ In exchange for granting precious

141. 545 F. Supp. 635,645 (D. Del. 1982).

142. 15 F. Cas. at 1019.

143. In other contexts, this probabilistic reasoning is commonplace. For example, venture capitalists balance the likelihood of seeing a return on an investment against the expected size of the return, should it materialize. The greater the rewards possible, the greater the risk they will tolerate. Any individual investment is unlikely to be profitable. But the few investments that are successful more than compensatc for the investments that are not successful. Arguing that financing contracts between venture capitalists and start up companics are void for lack of consideration, because the venture capitalists may not get anything in return for their investment, misunderstands what the venture capitalists are really paying for: a chance to earn large profits. A scheme of contract law that requircd each investment to yield a profit, no matter how meager, would wipe out venturc financing, and with it the high technology industry. This Comment's prospective utility doctrine allows the PTO to issue patents on inventions in exchange for the chance that the invention will be uscful; that is, if the PTO calculates that it is a reasonable "investment" of society's resources (in the form of patent protection). 
monopoly rights to the applicant, society may not receive a useful invention. Still, prospective utility's focus on future usefulness is more consistent than current utility doctrine with promoting the Constitution's commitment to the progress of the useful arts as it encourages the disclosure of information. ${ }^{144}$

\section{B. Determining Magnitude}

The second component of the algebraic formulation of prospective utility is the magnitude of the proposed use. This element of the formula is akin to the general utility requirement. An invention that addresses a pressing human need will have a high magnitude of usefulness. An invention that performs a trivial function will have a low magnitude of usefulness. While the magnitude of proposed use is inherently difficult to determine precisely, a precise determination is unnecessary. The utility requirement has always tolerated inventions of modest, perhaps even nominal, utility. ${ }^{145}$ The prospective utility formula, even if it is used only metaphorically, requires the patent law for the first time to consider the issue of the magnitude of the potential use for the invention.

The answers to two related questions raised in Section III.A.2.b., supra, to whom inust an invention have utility, and for what, are germane here. The PTO and courts rarely address these questions. ${ }^{146}$ For example, imagine that an inventor has developed a new type of contact lens. Its only use is in correcting a certain vision disorder. Several factors will influence the magnitude of the invention's usefulness. One of these factors is the group to whom the invention will be useful. If the invention corrects a common vision disorder, then the magnitude of its usefulness will tend to be greater. Conversely, if the vision disorder is very rare, then the magnitude of the usefulness of the invention will tend to be smaller.

Another factor affecting the magnitude of usefulness is the severity of the problem that the invention addresses. Using the above example, if the contact lenses correct a debilitating vision disorder, then the magnitude of their usefulness will tend to be greater. If the disorder is merely inconvenient to the people affected by it, then the magnitude of the usefulness of the invention will tend to be smaller.

A third factor in determining magnitude is the availability of substitutes for the new invention. If the invention is the first ever treatment

144. See supra note 116.

145. See supra notes $87-95$ and accompanying text.

146. See, e.g., In re Nelson, 280 F.2d 172, 180 (C.C.P.A. 1960) ("The Patent Office position seems to have been that there must be a presently existing 'practical' usefulness to some undefined class of persons. We have never received a clear answer to the question [sic] 'Useful to whom and for what?"'). 
for the vision disorder, then the magnitude of its usefulness will tend to be greater. If other treatments for the disorder exist in the prior art, then the new invention's usefulness will tend to be smaller. This factor recognizes that revolutionary inventions are inherently more useful, and therefore more worthy of patent protection, but correspondingly more difficult to prove effective; that is, revolutionary inventions will tend to have lower probability values within the prospective utility formula.

A fourth factor in establishing magnitude of usefulness is the similarity of the new invention to inventions of known usefulness in the prior art. The usefulness of the similar prior art invention can be used to estimate the magnitude of the usefulness of the new invention. Although this may seem to contradict the third factor, which rewards inventions for being unlike anything in the prior art, they are not inconsistent. They are two distinct and complimentary ways for the applicant to establish the magnitude of the prospective utility of her invention.

A fifth factor in the magnitude of usefulness inquiry is the magnitude of the claimed use versus the magnitude of other, foreseeable potential uses for the same invention. This factor addresses the problem of nominal utility. If a patent applicant recites a nominal utility, the magmitude of usefulness for her invention will be reduced if a person of ordinary skill would find the invention likely to have a much more significant use in the future. This factor is particularly germane to the problem of patenting ESTs. ${ }^{147}$

The question about what the invention must be used for in order for it to have utility asks which uses will be recognized as conferring utility to an invention. Under Judge Story's formulation of the utility requirement, only harmful or immoral uses are disallowed. Even without regard to moral utility, the answer to this question is dependent on subjective value judgments because it requires us to decide which areas of human endeavor are inherently more worthy of patent protection than others. With the demise of the moral utility doctrine, one might think it odd to withhold patent protection from certain classes of inventions, at least under the rubric of utility. ${ }^{148}$ Why would any use be insufficient to confer utility? Does it make sense to label an invention useless if it in fact has a use? How can some uses be deemed undeserving of patent protection, especially when nominal utility is apparently sufficient? Yet the Supreme Court in Manson, ${ }^{149}$ and the C.C.P.A. in In re Kirk ${ }^{150}$ and In

147. See supra notes $89-95$ and accompanying text.

148. Rejections premised on the invention's membership in a certain class of invention are more properly made under the doctrine of patentable subject matter. See supra notes 88-89 and accompanying text.

149. See supra notes $43-55$ and accompanying text.

150. See supra notes $56-65$ and accompanying text. 
re Joly ${ }^{151}$ decided that usefulness as a research tool or chemical intermediate is insufficient to confer utility. This is equivalent to saying that use by research scientists is not a recognized use for the purposes of satisfying the utility requirement. Recent Federal Circuit decisions ${ }^{152}$ and PTO directives ${ }^{153}$ have softened the impact of Manson and its progeny, but also have created uncertainty.

The prospective utility requirement, by focusing our attention on the progress of the useful arts, leads us to the correct standards for answering these questions. Who shall judge whether an invention is useful? The person of ordinary skill in the art evaluates the usefulness of an invention under prospective utility. For what must an invention be useful? For promoting the long-term progress of the useful arts. So understood, the utility requirement will prevent unfortunate holdings like that in Manson. ${ }^{154}$ Nonetheless, some classes of uses may be disallowed under the prospective utility doctrine as proof of market success for the purposes of establishing utility. For exanıple, success in selling an invention on the black market would not be valid evidence of utility because black market sales are, by definition, contrary to public policy. In effect, this aspect of the prospective utility requirenent is not very different froin the moral utility requirement.

\section{Combining Probability and Magnitude: The Formula at Work}

\section{Inventions with One Prospective Use}

Section III.A. discussed how to estiniate the probability that an invention without a present use will have utility in the foreseeable future. Section III.B. dealt with the magnitude of that prospective use. All that remams is to combime the two factors and analyze the result. To repeat, one should not take the prospective utility formula too literally. The inathematical precision suggested by the formula is illusory. The formula exists to focus our attention on the important factors of probable utility in the foreseeable future and the magnitude of that use. A low probability of usefulness deniands a high inagnitude of usefulness to

151. See id.

152. See supra notes $59-60$ and accompanying text.

153. See supra notes $61-65$ and accompanying text.

154. This is not to suggest that the courts and the PTO inust treat prospective use as a research tool as the equivalent of a prospective "end" use (e.g., treating disease). On the contrary, the prospective utility doctrine invites them to weigh prospective intermediate use and prospective end use differently, by recognizing that the inagnitude of the end use is greater than that of the intermediate use. This result would allow inventors to patent their research intermediates, but only if a sufficiently high probability of its use as an intermediate is proven. Note also that not all intermediate uses are necessarily equivalent. Some intermediate uses may have greater magnitudes of usefulness than others, based on the end result at which the research is aimed. 
provide patentable utility. Conversely, a low magnitude of usefulnessi.e., approaching nominal utility - will require a high probability of usefulness.

It is difficult to be any more precise than this. Fortunately, imprecision is acceptable. The standard to be applied is that of the person of ordinary skill in the relevant art. Would she be convinced that the combined factors of probability and magnitude support a finding that the claimed invention has patentable utility, defined as promoting progress of the useful arts? In many instances, a patent examiner or court could make this determination without explicitly breaking the inquiry down into "probability" and "magnitude." Doing so is merely a tool designed to help achieve the goal of determining a claimed invention's prospective utility. Whether this course is chosen will depend on both the patent applicant and examiner, or on the litigants in an infringement suit challenging the patent's validity for lack of utility, and the court hearing the case.

\section{Inventions with More Than One Prospective Use}

Although it is difficult to analyze utility in the abstract, one more issue should be considered: what should be done about inventions for which more than one utility is claimed? For example, imagine that a compound is claimed to cure headaches, prevent ulcers, and remove warts. (Recall that the applicant must demonstrate only one utility for her invention to obtain a patent). Two courses of action are available to the examiner or court. First, one might consider the probability and magnitude of each claimed utility separately. If none of the claimed uses is sufficient $\mathrm{m}$ itself to confer utility, then the invention is unpatentable. The better approach would add these separate probabilities into one overall "score" for the claimed invention. Using this approach, the fact finder might allow a claimed invention with a relatively low chance of being useful for any particular purpose to be patented by virtue of the relatively high chance that it will be useful for something. Under this approach, the examiner would have to be careful to avoid finding utility based on the conglomeration of a large number of feeble utility scores. This approach allows the fact finder to determine whether a person of ordinary skill in the art would find it likely that the claimed invention will proniote the progress of the art in the foreseeable future, rather than resolve whether there is one particular use that meets that criterion. 


\section{Interaction with Other Aspects of Patent Law}

\section{Enablement}

The utility requirement does not operate in a vacuum. It is only one of several requirements for patentability. ${ }^{155}$ The requirement of enablement is closely related to the utility requirement. Section 112 of the Patent Act, the enablement requirement, admonishes the applicant to describe her invention such that one of ordinary skill in the art may "use" it. An applicant cannot teach someone to use her invention if her invention is useless. ${ }^{156}$

At first, section 112's enablement requirement might seem to present an insurmountable obstacle to the prospective utility doctrine. One cannot teach a use that does not yet exist. The answer to the dilemma comes in the courts' interpretation of section 112. A disclosure is enabling if it allows a person of ordinary skill in the art to practice the invention without undue experimentation. ${ }^{157}$ The dividing line between undue and acceptable experimentation is determined case-by-case. Thus, under prospective utility, the applicant must know enough about her proposed use to write an enabling disclosure for it.

The enablement hurdle under section 112 is significant, but it does not undermine the operation of the prospective utility doctrine. Undue experimentation affords an applicant a significant range in which to operate. Currently, for example, the enablement requirement does not require an applicant claiming a pharmaceutical compound to detail how it is to be administered to humans. ${ }^{158}$ It is important to note in this context that the prospective utility of compounds founded on their potential beneficial uses will not confer to the applicant a patent on the potential beneficial use, even if the patent is granted. Her patent will cover only the compound itself. ${ }^{159}$ This is necessary to promote the progress of the useful arts. By allowing her patent on the compound alone, we introduce the product to the art, with the additional information that there is reasonable probability that the compound will be useful for treating a certain condition. Practitioners in the field are then at liberty, and have

155. See supra notes 4-9 and accompanying text.

156. See In re Fouche, 439 F.2d 1237, 1243 (C.C.P.A. 1971) ("[I]f such [inventions] are in fact useless, appellant's specifications cannot have taught how to use them."). But see In re Kirk, 376 F.2d 936, 954-55 (Fed. Cir. 1967) (denouncing this line of reasoning as "question begging").

157. The determination of whether an application is barred under the doctrine of undue experimentation requires a fact-intensive inquiry, see In re Wands, 858 F.2d 731, 737 (Fed. Cir. 1988) (listing eight factors to be considered) (citations omitted), and is soinewhat deferential to the applicant, see In re Angstadt, 537 F.2d 498, 504 (C.C.P.A. 1976) ("The key word is 'undue,' not 'experiunentation."').

158. See, e.g., U.S. Pat. No. 5,824,655, Anti-Transforming Growth Factor Beta Gene Therapy.

159. This is consistent with existing patent law. A patent protects only what it claims, not all that it discloses. See MERGES, supra note 1 , at 13 . 
the incentive, to develop any uses for the compound, knowing that if they succeed, they will have a patent on the resulting process. ${ }^{160}$ Perhaps just as significantly, practitioners will have an even greater incentive to design compounds similar to, but distinct from, the original compound because they will be able to patent both the compound and the use. This greater incentive corresponds with the greater progress such an achievement represents to the progress of the art.

\section{Infringement Suits}

Under current law, a defendant in an infringement suit can challenge the utility of the patented invention she is accused of infringing. If the defendant can establish that the invention did not have utility at the time the patent was awarded, then the patent is declared unenforceable, and the defendant wins the suit. While the prospective utility doctrine allows an invention to be patented without a current utility, the doctrine can also be reconciled with the utility defense to patent infringement. Recall that the prospective utility doctrine defines "useful" as promoting the progress of the useful arts. This condition is satisfied if, from the perspective of one of ordinary skill in the art, a device either has a use at filing, or there is a reasonable probability that there will be a reasonably important use for the invention in the foreseeable future. Courts will apply the same test in infringement suits. The test shifts from being prospective to being retrospective. In this respect, the prospective utility doctrine becomes more like the Hand formula for negligence, ${ }^{161}$ or the Basic test for materiality. ${ }^{162}$ The courts must use similar caution to avoid the blinding effects of hindsight. That the invention was found useful after it was patented (which presumably is true, if the defendant bothered to infringe the patent) does not mean necessarily that the invention satisfied the prospective utility test when its inventor sought a patent.

\section{CONCLUSION}

It is not necessarily a sign of weakness that a legal doctrine changes over time. This is especially true in the field of patent law, where the law

160. This creates a situation where each patentee holds a blocking patent to the use of the compound by others for that particular use. See supra notes 87-95 and 114-115 and accompanying text. Also, to optimally encourage the progress of the useful arts, the courts and the PTO will have to agree that disclosure of a prospective utility for a composition of matter does not render obvious thc use of that compound for that purposc. It should be thought of as being no more than a suggestion that the compound be tried for that purpose. Mere suggestions in the prior art do not render a claim nonobvious. See In re O'Farrell, 853 F.2d 894 (Fed. Cir. 1988) (holding that in order to establish obviousness, a suggestion to try in the prior art must be combined with evidence that it would be successful).

161. See supra note 127.

162. See supra note 126 and accompanying text. 
must accommodate not just new mventions, but entire new fields of endeavor. But when a doctrine is characterized by sharply contradictory court decisions in similar cases, as is true for the current utility doctrine, it is a sign that the policies and goals underlying the doctrine are not clear.

This Comment attempts to reconcile the Constitution, the Patent Act, and court decisions as they affect the utility requirement of patentability. Identification of the fundamental precepts of the utility requirement establish the basis for a new formulation of the utility doctrine-the prospective utility doctrine. This doctrine differs from previous definitions of utility in three major ways. First, it follows the Constitution in defining usefulness with respect to promotion of the progress of the useful arts. Second, it allows a patent applicant to establish utility by demonstrating that one of ordmary skill in the art would reasonably believe that her invention has a significant chance of being matched with a significant use in the foreseeable future. Third, it allows the applicant to present evidence of commercial success as evidence of utility.

Adoption of the prospective utility doctrine would have a number of salutary effects. First, it better realizes the Constitutional goal of promoting the progress of the useful arts. It does this in two ways. (1) It more efficiently promotes the progress of the useful arts. The prospective utility formula allows the PTO to issue a patent on an invention when it calculates that the value of the prospective future use of the invention overcomes the risk that the prospective future use of the invention will not be realized during the life of the patent. And (2) it provides better protection against the "patents as hunting licenses" problem identified by the Supreme Court in Manson. ${ }^{163}$ Using the prospective utility doctrine, the PTO could deny a nominal utility that has a very slight chance of being valuable in the future. ESTs ${ }^{164}$ might provide an example of this type of invention.

Second, it provides a clearer understanding than currently exists of the relationship between general utility and specific utility. Whether an invention has prospective utility depends in part on the magnitude of the potential use. The magnitude of the potential use is a manifestation of the invention's general utility, that is, the human need or desire satisfied by the invention. The probability that an invention will be found useful is a reflection of its specific utility. That a relatively low score for one of the factors can be compensated for by a relatively high score for the other allows the inventor to imcrease her chances of establishing her

163. See Brenner v. Manson, 383 U.S. 519 (1966); see also supra notes $43-55$ and accompanying text.

164. See supra notes $87-95$ and accompanying text. 
invention's utility, thereby making her invention known to the public, and so promoting the progress of the useful arts.

Third, the prospective utility doctrine harmonizes the utility requirements for all classes of inventions. Currently, the PTO's guidelines purport to apply equally to all classes of inventions, but this is not the case. By the PTO's act of administrative fiat, ${ }^{165}$ a person of ordinary skill in the art may be convinced that a pharmaceutical invention is currently useful-as the current utility doctrine requires-for treating disease based solely on evidence that it might be found useful at a future time.

Fourth, consistent with the goals of the PTO guidelines, the prospective utility doctrine will allow inventors in biotechnology and other emerging fields to secure protection for their inventions at an early stage of their inventions' development. ${ }^{166}$ This enables inventors to raise the large sums of money necessary to develop inventions into products.

165. See supra note 32 .

166. See supra note 82 and accompanying text. 